УдК 398

ББК 82.3
РЕЛИГИОЗНО-МИФОЛОГИЧЕСКИЕ ОБРАЗЫ И МОТИВЫ В НАРТСКОМ ЭПОСЕ БАЛКАРЦЕВ И КАРАЧАЕВЦЕВ

\author{
(C) 2020 г. Т.М. Хаджиева \\ Институт мировой литературы \\ им. А.М. Горького Российской академии наук, \\ Москва, Россия \\ Дата поступления статьи: 23 октября 2оІ9 г. \\ Дата публикации: 25 июня 2020 г.
}

DOI: I0.22455/2500-4247-2020-5-2-4I2-423

\begin{abstract}
Статья подготовлена в рамках проекта РФФИ №ㄱ8-ог2-оо266 «Нартский эпос народов Кавказа в кругу мировых эпических памятников: Опыт сравнительного исследования»
\end{abstract}

Аннотация: За свою многовековую историю балкарцы и карачаевцы создали чрезвычайно богатый фольклор. Центральное место в их устных поэтических произведениях занимает героический нартский эпос, являющийся одной из национальных версий общекавказской Нартиады. У балкарцев и карачаевцев, как и у других носителей Нартиады, сказания составляют ряд больших и малых циклов. Каждый цикл - это группа небольших по объему сказаний и песен о появлении на земле нартского племени; о различных этапах и событиях эпической жизни героев (рождение, богатырское детство, первый подвиг, женитьба, борьба с мифическими чудовищами, с кровником и т. д.). В эпосе балкарцев и карачаевцев есть оригинальные, самобытные песни и сказания, не имеющие параллелей ни в одной другой национальной версии Нартиады. Они относятся в основном к архаическому слою эпики, так как в них превалируют мотивы, связанные с тотемистическими, анимистическими, магическими и религиозными представлениями этих народов, у которых вплоть до XIX в. наряду с исламом бытовали некоторые пережитки первобытных форм религии и христианства. То, что балкарцы и карачаевцы продолжительное время поклонялись небу, огню, воде, небесным светилам, животным, деревьям и т. п. и что по их представлениям каждое явление, предмет имели своего Тейри (Тенгри), нашло отражение и в их нартском эпосе.

Ключевые слова: карачаевцы, балкарцы, нартский эпос, мифологические образы, мотив, культ, Тейри-Тенгри.

Информация об авторе: Танзиля Мусаевна Хаджиева - кандидат филологических наук, ведущий научный сотрудник, Институт мировой литературы им. А.М. Горького Российской академии наук, ул. Поварская, д. 25 а, г2го69 г. Москва, Россия.

E-mail: tanzila_@mail.ru

Для цитирования: Хаджиева Т.М. Религиозно-мифологические образы и мотивы в нартском эпосе балкарцев и карачаевцев // Studia Litterarum. 2020. T. 5, № 2. C. 4I2-423. DOI: IO.22455/250O-4247-202O-5-2-4I2-423 


\title{
RELIGIOUS AND MYTHOLOGICAL CHARACTERS AND MOTIFS IN THE NART EPIC BALKARS AND KARACHAI
}

This is an open access article

distributed under the Creative Commons Attribution 4.0 International (CC BY 4.0)

\author{
(C) 2020. T.M. Khadzhieva \\ A.M. Gorky Institute of World Literature \\ of the Russian Academy of Sciences, \\ Moscow, Russia \\ Received: October 23, 2019 \\ Date of publication: June 25, 2020
}

Acknowledgements: The article was supported by the Russian Foundation for Basic Research; project no I8-0I2-00266 "The Nart Epic of the Peoples of the Caucasus in the Circle of World Epic Monuments: The Experience of Comparative Research".

Abstract: During their many centuries of history, the Balkars and Karachays have created an extremely rich folklore. The heroic Nart epos occupies the central place in their oral poetic works; it is one of the national versions of the general Caucasus Nartiad. Among the Balkars and Karachays, as well as among other bearers of the Nartiad, the legends consist of a series of large and small cycles. Each cycle is a group of small (in bulk) legends and songs about the appearance of the Nart tribe on earth; about the various stages and events of the epic life of the heroes (birth, heroic childhood, the first exploit, marriage, and the struggle with mythical monsters, with a blood enemy, etc.). In the epos of the Balkars and Karachays, there are original individual songs and legends without parallels in any other national version of the Nartiad. They date basically from the archaic layer of the epic, since there is a predominance of motifs connected to the totemistic, animist, magic, and religious ideas of these peoples who, right up to the $19^{\text {th }}$ century, had some survivals of primitive forms of religion and Christianity, alongside Islam. The Nart epos also reflects the fact that the Balkars and Karachays used to worshiping the sky, fire, water, heavenly lights, animals, trees, stones, etc., and that according to their ideas, each phenomenon and thing had its own Teyri (Tengri).

Keywords: Karachays and Balkars, the Nart epic, mythological characters, mythological motifs.

Information about the author: Tanzily M. Khadzhieva, PhD in Philology, Leading Research Fellow, A.M. Gorky Institute of World Literature of the Russian Academy of Sciences, Povarskaya 25 a, I21069 Moscow, Russia.

E-mail: tanzila_@mail.ru

For citation: Khadzhieva T.M. Religious and Mythological Characters and Motifs in the Nart Epic Balkars and Karachai. Studia Litterarum, 2020, vol. 5, no 2, pp. 4I2-423.

(In English) DOI: I0.22455/2500-4247-2020-5-2-4I2-423 
One of the first researchers of Balkaro-Karachay mythology, L.I. Lavrov, pointed to the parallel existence in their religious beliefs of "ancient-Turkish, Alan and Caucasus strata”. In this connection he showed convincingly, on the basis of much folkloric and ethnographic material, that the Turkish layer was dominant in them.

Thus, in the religious beliefs of the Balkars and Karachays the supreme position is occupied by Teyri (Tengri) - the supreme god of all the Turko-Mongolian world (see $[2 ; 5 ;$ IO; II; 13; 23; 28] and others).

At the beginning of the $19^{\text {th }}$ century, G.Yu. Klaproth wrote that "the Balkars and Karachays honour a god named, not Allah but Tengri, in the capacity of the bearer of every kind of good thing” [I, p. 245]. Even at the beginning of the twentieth century the Karachays considered that "Teyri's will alone determined the life and death of a man" [12, p. 53]. Probably that is why in their algyshes (good wishes) and kargyshes (curses), which date from the most ancient genres of Turkish poetry, they always appeal to his name [12, pp. 380-409].

In the legends, Teyri steps out as "the creator and bearer of good things and blessings". When the Narts appeared, "Teyri of the Sky, Teyri of the Sun, Teyri of the Earth and Teyri of the Water took counsel and decided: Teyri of the Water will give water to the human race for them to drink; Teyri of the Earth took it on himself to grow the harvest and to feed man; Teyri of the Sun to shine with light; Teyri of the Sky to send rain" [I7, p. 302].

Teyri protects and helps the epic heroes in everything. In one of the Nart songs, an emegen (epic monsters) says to Sosuruk:

We would lay waste the land of the Narts,

We would extinguish their hearths. 
But the Teyris prevent us:

They help the land of the Narts [I7, p. I62].

The ancestors of the Balkars and Karachays, like many Turko-Mongolian peoples, used to organise special supplications and sacrifices to Teyri. Hymned prayers - psalms in honour of Teyri - were the chief component part of these mysteries. The epic text, "The supplication of the Narts to Teyri" [I7, p. 582], is probably a fragment of one such cult song. In it, the Narts not only swear by the name of Teyri, but they also appeal to him for help and they extol him, they even stress that Teyri's blood flows in their veins and that the Narts are a part of his flesh. With this, they call themselves "servants of Teyri", and display deep respect to him and worship before him. In this text, evidently, the propitiating imagery is linked to the insertion of such pagan hymns into the epos at the later stages of its development, when the consciousness of the people had already denied the imperative relations with the deity.

One of the specific traits of the Balkaro-Karachay epos is the absence of theomachist motifs (except for the Nart songs and legends about the struggle of Yoryuzmek with Fuk/Puk). We explain this by the fact that Christianity, and later Islam, were formally accepted by the ancestors of the Balkars and Karachays. They did not allow "the dogmatism of Islam into the depths of their soul. The religion remained as an outwardly social form, while its religious essence was filled up with survivals from the distant past, with a harmonious system of a whole range of ancient adats and with free fantasies in the field of artistic images, of distinctive rites and beliefs" [22, p. 63]. And since "the old mythological traditions are more firmly held in a place where the influence of the world religions is minimal or absent" [I9, p. I85], among the Balkars and Karachays the diverse ancient Turkish beliefs were conserved, and Teyri remained in their religious ideas "the god of gods" not only of the Turkish, but also of their Alan and underlying (Caucasus) deities.

After the complete establishment of Islam in Balkaria and Karachaya, the name of Teyri became for them one of the 99 epithets of Allah [28, p. I6r].

In the epos of the Balkars and Karachays, survivals are also preserved that are linked to reverence towards another deity of the ancient Turks - Umay [2I]. It seems to us that the Nart song "Umay-biyche" represents a fragment of one of the ritual songs in praise of this deity. It is possible that formerly it was performed 
during hunting rites, but with time, it became a part of a legend (song) of the hunting life of the Narts.

The epos of the Balkars and Karachays also reflects the cult of Suu Anasy, the Mother of Water, also well familia to some other Turkish peoples [I4, vol. 2, p. 47I]. In the epos, Suu Anasy appears as the actual foster mother of the little Satanay, and the godmother and foster mother of Debet [I7, pp. 302, 306].

Judging by the functions of the gods Teyri of the Water and Teyri of the Earth in the mythology of the Balkars and Karachays, there probably took place a splitting of the ancient-Turkish deity Yer-Su who, like Tengri, had a wide currency among all of the ethnic groups of the ancient-Turkish community [2I; II].

In the legends Teyri of the Earth helps and works with the Narts in everything ("Teyri and the Narts" [I7, p. 302], "Three Narts and three emegens" [I7, p. 486]). In the Debet cycle Teyri of the Earth personifies the feminine principle, she is the mother of the Nart blacksmith. Teyri of the Water (of the Sea) also protects the Narts. In the legend about the young Satanay he is portrayed as an all-powerful terrible creature, who is feared even by Teyri of the Sun and Teyri of the Moon [I7, p. 306].

In the epos of the Balkars and Karachays there are also preserved clear survivals of worship of the sun, who appears not only as Satanay's loving father, but also as the all-powerful protector of all the Teyris, one of the creators of the earth and the cosmos [I7, p. 302].

In the studied Nart epos, alongside the Turko-Mongolian deities there are also the subordinate deities of the Caucasus peoples: Apsaty and Elia.

In the past, one of the chief means of existence among the Balkars and Karachays was hunting. Evidently that wasa reason why, in their beliefs rites and folklore, Apsaty, the god of hunting and the patron of the mountains, forests and noble animals (deer, turs and so on) was allotted an important place. As with other Caucasus peoples, this image was significantly transformed over the centuries. Probably in the beginning Apsaty was a totem animal (a white deer). Later he takes on the appearance of the mistress of the deer (this is shown by the image of Apsaty's daughter Fatimat/Baydymat), and after that he appears in the form of a handsome grey-bearded venerable old man.

The ancient Balkars and Karachays, as other Caucasus peoples, deeply respected also the cult of Elia. Academic G.Yu. Klaproth wrote, "The Balkar people 
claim that he is often on the summit of the highest mountain; with singing and dancing they bring him as sacrifices: lambs, milk, cheese and beer" [I, p. 245].

In the Nart song, "Elia" this deity appears as a protector of the Narts in all their affairs (in hunting for bison, in campaigns and so on) and as a terrible all-shattering patron of the Nart warriors, who with one light blow can reduce the Narts' enemies to ashes.

In the mythological system of the Balkars and Karachays, as also among many peoples of the world, a special place is occupied by the sacred trees, which indicate the sacral centre of a rite $[26 ; 4 ; 27 ; 8$ and others]. Judging by the fact that these cult trees (Raubazy in Balkaria; Zhangyz terek - solitary tree, in Karachaya) are addressed with various requests, universal functions can be attributed to them. As also among the ancient Turks, the trees are dedicated to Teyri [I4, vol. 2, p. 537] and seem to be mediators between him and the people [I2, pp. 4I-42].

In the Nart epos of the Balkars and Karachays, survivals associated with the cult of the tree meet in the song "The magic staff of the Narts" [I7, p. 584]. In the song, it says that the Narts had a stuff that cured the Narts of all illnesses, and sowed wholesale death among the emegens. "One day the Narts went out to fight with the emegens and wiped them out with this staff" [I7, p. 584].

The old age of the motif underlying this song is shown by its hymn of praise character and that its basis is composed of traditional incantations and wishes, typical of the cult algyshes and kargyshes that are widely represented in the folklore of the Balkars and Karachays.

In this epos, the chains ("How Yoryuzmek fought in the sky with Fuk" [I7, p. 3II]) and ropes ("How the Narts and Satanay resettled in the sky" [I7, p. 3II]) coming down from the heavens are semantically equivalent to the world tree. In the epos, they are one of the means of communication between the Narts and the upper world.

The cult of mountains and stones also is reflected in the Nart songs - they are animated and even possess the gift of speech ("The birth of the Nart blacksmith Debet" [I7, p. 302], "How evil entered the Nart race” [I7, p. 404]).

In one of the variants of the legend about the birth of Sosuruk, Satanay addresses the mountains, as if addressing live almighty creatures, and asks them to protect her son ("The birth of Sosuruk" [I7, p. 365]).

The cult of a stone has something in common with the cosmogonic ideas of the ancient Balkars and Karachays, who believed in the heavenly origin of stones, 
gold and silver; and believing that iron, stones and the stars are related ("Yoryuzmek and the emegens" [I7, p. 339]; "Debet, the heavenly blacksmith” [I7, p. 596]; "Teyri and the Narts" [I7, p. 302]).

As is well-known, the wolf was one of the totems of the Turko-Mongolian peoples. We find survivals of the worship of the wolf also in the epos of the Balkars and Karachays, whose ancestors deeply honoured the wolf: Yoryuzmek, according to some variants, was nourished by a she-wolf; one of his permanent attributes is the wolf-skin coat (see [I7, p. 38; 24, p. 260] and others).

Yoryuzmek's fur coat is probably not merely a symbol of his power and strength, and a mark distinguishing him from the other Narts as their leader, and the patriarch of the tribe. Here, it seems to us, is a reflection and a survival of a cult of the wolf.

The wolf-skin coat, which Yoryuzmek always wore thrown over his shoulders, was also a symbol of his connection with the wolves. After all, in the legend "The birth of Yoryuzmek", this is indicated directly: "...After sucking the milk of the she-wolf, he (Yoryuzmek) has become related to the wolves", says a Nart shepherd to Debet [I7, p. 308].

The ancients believed that when a man is arrayed in the skin of a totem animal, as if he were transformed into it. This is clearly shown by the Nart songs and legends about Yoryuzmek's meeting with the shaytans. The ancestors of the Balkars and Karachays thought that the shaytans, by wishing, could be invisible for all living creatures on the earth, except wolves, and that the latter always lie in wait for and eat newly-born shaytans ("Where the almostus came from" [I7, p. 580]). Therefore, among the Balkars and Karachays any essential parts from the body of a wolf (the chief enemy of the shaytans) are the most effective protection against the unclean powers. That is why, at Yoryuzmek's meeting with the shaytans, his fur-coat induced in them an indescribable terror. Their terror was so great that even the words "wolf-skin coat" could not be mentioned, and they called the fur-coat "zhelpegey" ("what is thrown over the shoulders"), and, by insisting that Yoryuzmek should take it off, they were trying to get the Nart once more to attain his human reality, and consequently also his vulnerability.

In this version, besides the cult of the wolf, one can also observe traces of worship of the raven ("Elia” [I7, p. 582]), who was one of the ornithological totems of the ancient Turks and Mongols. 
The specific character of the studied version is that its main epic theme is the struggle of the Narts with the mythological emegen-monsters. "Between the Narts and the emegens a continual struggle was carried on, in which thanks to their intellectual superiority the Narts always were left the winners... The Narts nourished a perpetual hatred towards them because the emegens used to eat human flesh" [25, p. III]. The emegens were not only the permanent epic enemies of the Narts, but they were the source of evil and chaos on the earth.

In the tales, which are well-known also to other bearers of the Nartiad, the giant is presented in the mainstream of general Nart traditions, for example in the variants about the blinding by Yoryuzmek (Sosuruk) of the giant Cyclops. However, in the legends that are significantly different from the other versions, or were recorded only in the given epos, there exists a striking similarity, and sometimes even an absolute coincidence, of the image and function of the Balkaro-Karachay emegens with the fabulous and epic monsters of the Turkish and Mongolian peoples - the Yakut abaasy, the Mongol mangus, the Buryat mangadhay, the Kalmyts mus and mangus, and so on (see [20, pp. 43-52; I8, pp. III-I24] and others).

In this epic work of the Balkars and Karachays, as in other national versions $[15 ; 16 ; 9 ; 3 ; 6 ; 7]$, besides the religious-mythological outlook of the creators of the epos there are reflected also their communal institutions (the tyore, kunaks and so on), the rituals, some cultural elements of the material culture, elements of household activities and so on. 


\section{Список литературы}

Адыги, балкарцы и карачаевцы в известиях европейских авторов. Нальчик: Эльбрус, г974. 635 с.

Азаматов К.Г. Пережитки язычества в верованиях балкарцев // Из истории феодальной Кабардино-Балкарии. Нальчик: КБНИИ, І98І. С. I43-г6I. Алиева А.И. Адыгский нартский эпос. М.; Нальчик: Эльбрус, г969. І68 с. Вейденбаум Е.Г. Священные рощи и деревья у кавказских народов // Известия кавказского отдела Императорского русского географического общества. СПб., І878. № 3. С. I53-I79.

Гумилев Л.Н. Древние тюрки. М.: Наука, 1967. 247 с.

Далгат У.Б. Героический эпос чеченцев и ингушей. М.: Наука, г972. 467 с. Джапуа 3.Д. Абхазский нартский эпос: Текстология. Семантика. Поэтика. М.: Наука, Восточная лит., 20I6. 38г с.

Зеленин Д. Тотемы-деревья в сказаниях и обрядах европейских народов. М.; Л.: Изд-во Акад. наук СССР, І937. 77 с.

Ингушский нартский эпос / сост. И.А. Дахкильгов. Нальчик: Тетраграф, 2012. 594 с. История авган Мойсея Каганкатваци, писателя Х в. СПб.: Тип. Академии наук, I86I. 376 c.

Кляшторный С.Г. Мифологические сюжеты в древнетюркских памятниках // Тюркологический сборник і977. М.: Наука, І98г. С. ІІ7-І38.

Карачаево-балкарский фольклор: Хрестоматия / сост., авт. предисл.

Т.М. Хаджиева. Нальчик: Издат. центр «Эль-Фа», І996. 592 с.

Малкондуев Х.Х. Отголоски тенгрианства в карачаево-балкарском фольклоре // Тезисы Всесоюзной сессии по итогам полевых этнографических исследований І980-І98г гг. Ташкент: [Б.и.], І986. С. І53-І54.

Мифы народов мира: энциклопедия: в 2 т. М.: Сов. энциклопедия, I980-I982. Нарты. Адыгский героический эпос / сост. А.И. Алиева, А.М. Гадагатль, 3.П. Кардангушев. М.: Наука, І974. 420 с.

Нарты. Осетинский героический эпос / сост. Т.А. Хамицаев, А.Х. Бязыров, научный консультант В.И. Абаев. М.: Наука, І989-І990. Кн. I-3.

Нарты. Героический эпос балкарцев и карачаевцев / сост.: Р.А.-К. Ортабаева, Т.М. Хаджиева, А.З. Холаев; вступит. ст., коммент. и глоссарий Т.М. Хаджиевой, отв. ред. А.И. Алиева. М.: Наука, г994. 654 с.

Неклюдов С. Ю. Героический эпос монгольских народов. М.: Наука, I984. 509 с. Неклюдов С.Ю. Мифология тюркских и монгольских народов // Тюркологический сборник. I977. М.: Наука, І98г. С. 183-202.

Поппе Н.Н. Халха-монгольский героический эпос. М.; Л.: Изд-во Академии наук CССР, І937. $128 \mathrm{c.}$

Потапов Л.П. Умай - божество древних тюрков // Тюркологический сборник. I972. М.: Наука, І973. С. 265-286. 
Рогаль-Левицкий Дм. Песенное творчество карачаевцев // Советское искусство. 1928. № 3. С. 58-65.

23 Стеблева И.В. К реконструкции древнетюркской религиозно-мифологической системы // Тюркологический сборник. І972. М.: Наука, І973. С. 213-226.

24 Тульчинский Н.П. Поэмы, легенды, песни, сказки и пословицы горских татар Нальчикского округа Терской области // Терский сборник на І904. Владикавказ: [Б.и.], г903. Вып. 6. С. 249-334.

25 Урусбиев С.-А. Сказания о нартских богатырях у татар-горцев Пятигорского округа Терской области // Сборник материалов для описания местностей и племен Кавказа. г88г. Вып. г, отд. 2. С. г-УІІг; г-42.

26 Фрэзер Д. Золотая ветвь. М.: Политиздат, І980. 832 с.

27 Чурсин Г. Почитание деревьев на Кавказе // Кавказ. Ил. прилож. 1903. № 5.

28 Шаманов И.М. Древнетюркское верховное божество Тенгри (Тейри) в Карачае и Балкарии // Проблемы археологии и этнографии Карачаево-Черкесии. Черкесск: Карачаево-Черкес. НИИ истории, филологии и экономики, I982. С. I55-I70.

\section{References}

I Adygi, balkartsy i karachaevtsy v izvestiiakh evropeiskikh avtorov [European authors on Adygs, Balkars, and Karachais]. Nal'chik, El'brus Publ., I974. 635 p. (In Russ.)

2 Azamatov K.G. Perezhitki iazychestva v verovaniiakh balkartsev [Remnants of paganism in the beliefs of the Balkars]. In: Iz istorii feodal'noi Kabardino-Balkarii [From the history of the feudal Kabardino-Balkaria]. Nal'chik, KBNII Publ., I98I, pp. I43-I6I. (In Russ.)

3 Alieva A.I. Adygskii nartskii epos [Adyghe Nart epic]. Moscow, Nal'chik, El'brus Publ., I969. I68 p. (In Russ.)

4 Veidenbaum E.G. Sviashchennye roshchi i derev'ia u kavkazskikh narodov [Sacred groves and trees among the Caucasian peoples]. In: Izvestiia kavkazskogo otdela Imperatorskogo russkogo geograficheskogo obshchestva. St. Petersburg, I878, no 3, pp. I53-I79. (In Russ.)

5 Gumilev L.N. Drevnie tiurki [Ancient Turks]. Moscow, Nauka Publ., I967. 247 p. (In Russ.)

6 Dalgat U.B. Geroicheskii epos chechentsev $i$ ingushei [Heroic epic of Chechens and Ingush]. Moscow, Nauka Publ., I972. 467 p. (In Russ.)

7 Dzhapua Z.D. Abkhazskii nartskii epos: Tekstologiia. Semantika. Poetika [Abkhazian Nart Epic: Textology. Semantics. Poetics]. Moscow, Nauka, Vostochnaia lit. Publ., 2016. 38I p. (In Russ.)

8 Zelenin D. Totemy-derev'ia v skazaniiakh i obriadakh evropeiskikh narodov [Tree totems in the tales and rites of European nations]. Moscow, Leningrad, Izdatel'stvo Akademii nauk SSSR Publ., I937. 77 p. (In Russ.) 
Ingushskii nartskii epos [Ingush Nart epic], comp by I.A. Dakhkil'gov. Nal'chik, Tetragraf Publ., 20I2. 594 p. (In Russ.)

Istoriia avgan Moiseia Kagankatvatsi, pisatelia Xv. [The story of Agan Moysey Kagankatvatsi, a Io ${ }^{\text {th }}$ century author]. St. Petersburg, Tipografiia Akademii nauk Publ., I86I. 376 p. (In Russ.)

Klyashtorny S.G. Mifologicheskie syuzhety v drevnetyurkskikh pamyatnikakh [Mythological subjects in ancient Turkic monuments]. In: Tyurkologichesky sbornik, 1977. Moscow, Nauka Publ., I98I, pp. II7-I38. (In Russ.)

Karachaevo-balkarskii fol'klor. Khrestomatiia [Karachay-Balkarian folklore. Anthology], comp., introd. by T.M. Khadzhieva. Nal'chik, Izdatel'skii tsentr “El'-Fa” Publ., I996. 592 p. (In Karachay-Balkar)

Malkonduev X.X. Otgoloski tengrianstva v karachaevo-balkarskom fol'klore. [Echoes of Tengrianism in Karachay-Balkarian folklore]. In: Tezisy Vsesoiuznoi sessii po itogam polevykh etnograficheskikh issledovanii I980-I98I gg. Tashkent, I986, pp. I53-I54. (In Russ.)

Mify narodov mira: entsiklopediia: $v 2 t$. [Myths of the peoples of the world: encyclopedia: in 2 vols.] Moscow, Sovetskaia entsiklopediia Publ., I980-I982. (In Russ.)

Narty. Adygskii geroicheskii epos [Adyghe heroic epic], comp. by A.I. Alieva, A.M. Gadagatl', 3.P. Kardangushev. Moscow, Nauka Publ., I974. 420 p. (In Russ.)

Narty. Osetinskii geroicheskii epos [The Narts. Ossetian heroic epic], comp. by T.A. Khamitsaev, A.X. Biazyrov, scientific consultant by V.I. Abaev. Moscow, Nauka Publ., I989-1990. Book I-3. (In Russ.)

Narty. Geroicheskii epos balkartsev $i$ karachaevtsev [The Narts. The heroic epic of the Balkars and Karachays], comp. by R.A.-K. Ortabaeva, T.M. Khadzhieva, A.Z. Kholaev; introd., comm. and glossary by T.M. Khadzhieva, ex. ed. by A.I. Alieva. Moscow, Nauka Publ., I994. 654 p. (In Russ.)

Nekliudov S.Iu. Geroicheskii epos mongol'skikh narodov [Heroic epic of the Mongolian peoples]. Moscow, Nauka Publ., I984. 509 p. (In Russ.)

Nekliudov S.Iu. Mifologiia tiurkskikh i mongol'skikh narodov [Mythology of Turkic and Mongolian peoples]. In: Tiurkologicheskii sbornik. I977 [Turkic collection. I977]. Moscow, Nauka Publ., I98I, pp. 183-202. (In Russ.)

Poppe N.N. Khalkha-mongol'skii geroicheskii epos [Khalkha Mongolian Heroic Epic]. Moscow, Leningrad, Izdatel'stvo Akademii nauk SSSR Publ., I937. I28 p. (In Russ.)

I Potapov L.P. Umai - bozhestvo drevnikh tiurkov [Umai - the deity of the ancient Türks]. In: Tiurkologicheskii sbornik. I972 [Turkic collection. I972]. Moscow, Nauka Publ., 1973, pp. 265-286. (In Russ.)

2 Rogal'-Levitskii Dm. Pesennoe tvorchestvo karachaevtsev [Songwriting of Karachais]. Sovetskoe iskusstvo, 1928, no 3, pp. 58-65. (In Russ.)

Stebleva I.V. K rekonstruktsii drevnetiurkskoi religiozno-mifologicheskoi Sistemy [On the reconstruction of the ancient Turkic religious and mythological system]. In: 
Tiurkologicheskii sbornik. 9972 [Turkic collection. I972]. Moscow, I973, pp. 213-226. (In Russ.)

24 Tul'chinskii N.P. Poemy, legendy, pesni, skazki i poslovitsy gorskikh tatar Nal'chikskogo okruga Terskoi oblasti [Poems, legends, songs, and tales of the proverbs mountain Tatars of the Nal'chikskovo district of the Terek region]. In: Terskii sbornik na 1904 [Terek collection for I904]. Vladikavkaz, I903, issue 6, pp. 249-334. (In Russ.)

25 Urusbiev S.-A. Skazaniia o nartskikh bogatyriakh u tatar-gortsev Piatigorskogo okruga Terskoi oblasti [Tales of the Nart heroes among the Tatars-Highlanders Pyatigorsk district of Terek region]. In: Sbornik materialov dlia opisaniia mestnostei i plemen Kavka$z a$ [A collection of materials for describing localities and tribes of the Caucasus], I88I, issue I, depart. 2, pp. I-Uiı; I-42. (In Russ.)

26 Frezer D. Zolotaia vetv' [The golden bough]. Moscow, Politizdat Publ., I980. 832 p. (In Russ.)

27 Chursin G. Pochitanie derev'ev na Kavkaze [The veneration of trees in the Caucasus]. Kavkaz. Il. prilozh., I903, no 5. (In Russ.)

28 Shamanov I.M. Drevnetiurkskoe verkhovnoe bozhestvo Tengri (Teiri) v Karachae i Balkarii [The ancient Turkic supreme deity Tengri (Theories) in Karachai and Balkaria]. In: Problemy arkheologii i etnografii Karachaevo-Cherkesii [Problems of archeology and ethnography of Karachay-Cherkessia]. Cherkessk, Karachay-Cherkess. Research Institute of History, Philology and Economics, I982, pp. I55-I70. (In Russ.) 